\title{
Article \\ Phytochemical Analyses, Antioxidant and Anticancer Activities of Ethanolic Leaf Extracts of Moringa oleifera Lam. Varieties
}

\author{
Bilques Farooq ${ }^{1}$, Bhupendra Koul ${ }^{1, *(D)}$, Deveshi Mahant ${ }^{1}$ and Dhananjay Yadav ${ }^{2, *(D)}$ \\ 1 School of Bioengineering and Biosciences, Lovely Professional University, Phagwara 144411, India; \\ bilquesfarooq123@gmail.com (B.F.); deveshi.selina@gmail.com (D.M.) \\ 2 Department of Medical Biotechnology, Yeungnam University, Gyeongsan 38541, Korea \\ * Correspondence: bhupendra.18673@lpu.co.in (B.K.); dhanyadav16481@gmail.com (D.Y.); \\ Tel.: +91-9454320518 (B.K.); +82-1022021191 (D.Y.)
}

check for updates

Citation: Farooq, B.; Koul, B.; Mahant, D.; Yadav, D. Phytochemical Analyses, Antioxidant and Anticancer Activities of Ethanolic Leaf Extracts of Moringa oleifera Lam. Varieties. Plants 2021, 10, 2348. https://doi.org/ $10.3390 /$ plants10112348

Academic Editor: Francesca Pintus

Received: 23 September 2021

Accepted: 25 October 2021

Published: 30 October 2021

Publisher's Note: MDPI stays neutral with regard to jurisdictional claims in published maps and institutional affiliations.

Copyright: (c) 2021 by the authors. Licensee MDPI, Basel, Switzerland. This article is an open access article distributed under the terms and conditions of the Creative Commons Attribution (CC BY) license (https:// creativecommons.org/licenses/by/ $4.0 /)$.

\begin{abstract}
Moringa oleifera Lam. (Moringaceae) is revered as s 'miracle tree' due to its remarkable nutritional, medicinal and industrial uses. In our study, a comparative analysis of the nutritional parameters (antioxidant activity, sugar content-TSS, total soluble proteins-TSP and mineral contents), phytochemicals (HPLC analysis of four anticancer compounds), and cytotoxicity of M. oleifera leaf extracts (MLEs) of five selected varieties (conventional, PKM-1, PKM-2, ODC, and Jaffna), was performed. Jaffna variety possessed the highest antioxidant activity (FRAP) followed by other four varieties. The trend observed was: Jaffna $(9.47 \mu \mathrm{g} / \mathrm{mL}, 18.48 \mu \mathrm{g} / \mathrm{mL}, 29.39 \mu \mathrm{g} / \mathrm{mL}$, and $35.37 \mu \mathrm{g} / \mathrm{mL})>$ PKM-1 $(4.82 \mu \mathrm{g} / \mathrm{mL}, 7.63 \mu \mathrm{g} / \mathrm{mL}, 22.33 \mu \mathrm{g} / \mathrm{mL}$, and $27.71 \mu \mathrm{g} / \mathrm{mL})>$ PKM-2 $(2.10 \mu \mathrm{g} / \mathrm{mL}, 7.04 \mu \mathrm{g} / \mathrm{mL}$, $13.18 \mu \mathrm{g} / \mathrm{mL}$, and $21.78 \mu \mathrm{g} / \mathrm{mL})>$ ODC $(0.17 \mu \mathrm{g} / \mathrm{mL}, 2.10 \mu \mathrm{g} / \mathrm{mL}, 4.41 \mu \mathrm{g} / \mathrm{mL}$ and $13.94 \mu \mathrm{g} / \mathrm{mL})>$ Conventional $(0.05 \mu \mathrm{g} / \mathrm{mL}, 1.08 \mu \mathrm{g} / \mathrm{mL}, 2.86 \mu \mathrm{g} / \mathrm{mL}$, and $5.40 \mu \mathrm{g} / \mathrm{mL})$, total soluble proteins (TSP) [0.69 \pm 0.01 and $0.94 \pm 0.01 \mu \mathrm{g} / \mathrm{mL}$ (young and mature stage, respectively)], sugar content (TSS) $[0.39 \pm 0.01$ and $0.51 \pm 0.01 \mu \mathrm{g} / \mathrm{mL}$ (young and mature stage, respectively)], chlorophyll content [1.07 \pm 0.01 (plantlet stage), $1.36 \pm 0.003$ (vegetative-stage), $0.82 \pm 0.004$ (reproductive stage) $\mathrm{mg} / \mathrm{g}]$, followed by the other four varieties. The trend observed for cytotoxic activities of ethanolic MLEs on HepG2 cell line, based on the IC50 values, was conventional $(1.22 \mathrm{mg} / \mathrm{mL})>$ ODC $(0.90 \mathrm{mg} / \mathrm{mL})>$ PKM-2 $(0.65 \mathrm{mg} / \mathrm{mL})>$ PKM-1 $(0.35 \mathrm{mg} / \mathrm{mL})>$ Jaffna $(0.15 \mathrm{mg} / \mathrm{mL})$. The results of HPLC quantification of anticancer compounds [beta-sitosterol $(0.244 \%)$, quercetin $(0.216 \%)$, kaempferol $(0.013 \%)$, and moringin $(0.063 \%)$ ] was also in consonance with that of MTT assay. In summary, the trend observed in all the parameters tested was Jaffna > PKM-1 > PKM-2 > ODC > conventional. Thus, Jaffna variety has a better potential to combat malnutrition and cancer and must be recommended for commercial plantations.
\end{abstract}

Keywords: Jaffna; HPLC; FRAP; moringin; MTT assay; HepG2

\section{Introduction}

Moringa oleifera Lam. (Moringaceae) is a 'miracle tree' which possesses excellent medicinal and nutritional properties and can combat malnutrition among the young population of the world who are devoid of a nutritious diet [1,2]. It is interesting to note that every part of this tree (leaves, flower, pods, stem-bark, roots, and gum) exhibits one or more nutritional and pharmacological properties. It is a proven superfood that harbors several minerals, vitamins, amino acids, and fatty acids [3-8].

The pharmacological properties such as cardiac stimulant, anti-oxidant, antiinflammatory, anti-bacterial, anti-fungal, anti-pyretic, anti-epileptic, anti-cancer, antitumor, anti-ulcer, diuretic, anti-hypertensive, anti-diabetic, anti-ulcer and hepatoprotective can be attributed to the presence of bioactive compounds such as $3-\mathrm{O}-\left(6^{\prime}-\mathrm{O}\right.$-oleoyl- $\beta$ Dglucopyranosyl)- $\beta$-sitosterol, 4-(4'-O-acetyl- $\alpha$-L-rhamnopyranosyloxy) benzyl isothiocyanate, 4-( $\alpha$-L-rhamnopyranosyloxy) benzyl glucosinolate, ascorbic acid, isoquercetin, kaempferitrin, Kaempferol, moringine, niazimicin, niaziminin A and B, niazirin, niazirinin, 
O-ethyl-4-( $\alpha$-Lrhamnosyloxy) Benzylcarbamate, pterygospermin, quercetin, $\beta$-carotene, $\beta$-sitosterol, and $\beta$-sitosterol-3-O- $\beta$-Dglucopyranoside $[9,10]$. The consumption of $M$. oleifera leaf extracts (MLE) can be beneficial in the treatment of altogether 300 diseases including arthritis, cancer, brain dysfunction, diabetes, hypertension, obesity, skin diseases, etc. [11-13]. Moreover, adding Moringa leaf powder to the diet of lactating mothers improves the quality and nutrient content of milk, for the proper growth of the child [14]. Besides nutritional and medicinal properties, it has several industrial applications as well. The leafy biomass is itself used as food and fodder while the MLE has plant growthenhancing potential [15]. The seed oil is a source of biopesticide, biodiesel, and lubricant and also finds application in cosmetics [16]. Moreover, the seed powder has biosorbent property and can therefore be deployed in water purification regimes $[3,9,17,18]$.

In the recent past, the public and the private sectors have shown interest in its commercial plantation due to its exceptional nutritional and therapeutic values, increasing demand for value-added products, potential to be a source of biofuel, climate resilience, and adaptability to new regions. Moringa tree is also a suitable candidate for reforestation program. Its cultivation shall be an alternative source of income for the poor farmers and shall open new vistas for the employment-seeking youth of rural communities $[9,16,19]$.

In our previous study, we performed a comparison of antibacterial and plant growth enhancer property of five (conventional, PKM-1, PKM-2, ODC, and Jaffna) M. oleifera varieties [9]. Among them, Jaffna exhibited excellent bacteriostatic and plant growth enhancer properties (Supplementary Tables S1 and S2). The aim of our study was to quantify the amount of protein, sugar, chlorophyll, and bioactive compounds present in leaves of five varieties of $M$. oleifera. The research also focuses on the antioxidant and anticancer activity of $M$. oleifera varieties, so as to suggest the elite variety. Jaffna leaf extract showed a higher amount of protein, sugar, chlorophyll, and bioactive compounds and also performed well in antioxidant and anticancer activities, compared to others. Hence, Jaffna is a promising variety that can be used to treat deficiency diseases and can be deployed in the food and beverage industries.

\section{Material and Methods}

\subsection{Plant Material}

Healthy and uniform seeds of five Moringa oleifera Lam. varieties [conventional, PKM1 (Periyakulam-1), PKM-2 (Periyakulam-2), ODC (Oddanchatram), and Jaffna)], were procured from Tamil Nadu Agriculture University (TAU), India. The wings of the seeds were removed and were soaked in water for $15 \mathrm{~min}$. The seeds were then wrapped in wet paper towels and incubated for sprouting at $25{ }^{\circ} \mathrm{C}$ for three days. The seedlings of the aforementioned varieties were transferred into separate plastic pots $(3.9 \times 3.5$ inches) filled with soil and soilrite (soil conditioning mixture) in 1:1 ratio $(w / w)$ and kept in a polyhouse maintained at $30^{\circ} \mathrm{C}$, relative humidity $(\mathrm{RH})$ of $60 \%$, with a $16 / 8 \mathrm{~h}$ light/dark photoperiod.

\subsection{Moringa Leaf Extract (MLE) Preparation}

Fresh leaves of 3 months and 15 months old plants were harvested, shade dried (5 days), powdered, and sieved through a mesh (pore size: 297 microns). Leaf powder (50 g each) of all the varieties was suspended in conical flasks containing $80 \%$ ethanol $(100 \mathrm{~mL})$ and incubated on a rotary shaker set at $250 \mathrm{rpm}$, for $6 \mathrm{~h}$. The filtered MLEs were concentrated at $40-45^{\circ} \mathrm{C}$ on a rotary evaporator set at $200 \mathrm{rpm}$. Thereafter, MLEs $(\sim 5 \mathrm{mg} / \mathrm{mL})$ were labeled and refrigerated for further use [20]. MLEs were used for the estimation of total soluble sugars (TSS) and total soluble proteins (TSP).

\subsection{Estimation of Sugar Content}

The sugar content of MLEs of five varieties at two different stages of development (young: 3 months old; mature stage: 15 months old) was estimated by the procedure of DuBois [21]. Phenol $(1 \mathrm{~mL})$ and sulphuric acid $(5 \mathrm{~mL})$ were added sequentially to the MLE (2 $\mathrm{mL}$ each of five different varieties). The test tubes containing the reaction mixture 
were incubated for $20 \mathrm{~min}$ in a water bath set at $30^{\circ} \mathrm{C}$. In a hot acidic medium, glucose becomes dehydrated to hydroxymethylfurfural which, in the presence of phenol, gives a yellow-brown color that can be read and measured spectrophotometrically at $490 \mathrm{~nm}$ [22] Glucose was used to plot the standard curve.

\subsection{Estimation of Total Soluble Protein (TSP)}

The total soluble protein (TSP) was measured by the procedure of Lowry et al. [23]. The phenolics and pigments were removed by the procedure of Mattoo et al. (1986) [24]. MLEs $(200 \mu \mathrm{L})$ of each of the five varieties, at young (3-months-old) and mature (15-monthsold) growth stage, were taken in test tubes (triplicate) and the volume was adjusted to $1 \mathrm{~mL}$ with deionized water. Thereafter, freshly prepared Lowry's reagent $\left[4 \% \mathrm{CuSO}_{4} \cdot 5 \mathrm{H}_{2} \mathrm{O}\right.$ $(w / v)+2 \%$ sodium carbonate $(w / v)+1 \% \operatorname{SDS}(w / v), 0.4 \% \mathrm{NaOH}(w / v)$ and $0.16 \%$ sodium potassium tartrate $(w / v)]$ was added and the reaction mixture was incubated for an hour at RT prior to the addition of the Folin-Ciocalteu reagent (FCR). The absorbance was read at $660 \mathrm{~nm}$ spectrophotometrically [25]. BSA was used as a standard protein.

\subsection{Estimation of Chlorophyll Content}

The chlorophyll a, b, and total chlorophyll content was estimated by the IUPAC standardized procedure of Arnon [26]. Fresh leaves (5 g) of M. oleifera varieties (5 varieties) were homogenized ( $80 \%$ acetone) and filtered through Whatman filter paper no. 1 . The absorbance of the filtrate was read spectrophotometrically at 663 and $645 \mathrm{~nm}$ and the calculations were performed using the formula given below:

$$
\begin{gathered}
\text { Chlorophyll a }(\mathrm{mg} / \mathrm{g} \text { FW })=[(12.7 \times \text { A663 })-(2.6 \times \text { A645 })] \times \text { acetone }(\mathrm{mL}) / \text { leaf tissue }(\mathrm{mg}) \\
\text { Chlorophyll b }(\mathrm{mg} / \mathrm{g} \text { FW })=[(22.9 \times \text { A645 })-(4.68 \times \text { A663 })] \times \text { acetone }(\mathrm{mL}) / \text { leaf tissue }(\mathrm{mg}) \\
\text { Total chlorophyll content }=\text { Chlorophyll a }+ \text { Chlorophyll b }
\end{gathered}
$$

\subsection{Estimation of Mineral Content}

To estimate the mineral contents, $1 \mathrm{~g}$ shade-dried leaves of each of the five varieties was powdered separately and the leaf powder was transferred into separate Erlenmeyer flasks (100 mL capacity) and were digested in triacid containing nitric, perchloric and sulphuric acids (9:3:1 $v / v)$, for estimation of potassium and phosphorus, and in diacids containing nitric and perchloric acids (9:4), for estimation of calcium, sulphur, nitrogen, sodium, and carbon. Thereafter, $3 \mathrm{~g}$ of catalyst mixture $\left[\mathrm{CuSO}_{4} \cdot 6 \mathrm{H}_{2} \mathrm{O}(20 \mathrm{~g})+\right.$ Se-powder $\left.(1 \mathrm{~g})+\mathrm{HgO}(3 \mathrm{~g})+\mathrm{K}_{2} \mathrm{SO}_{4}(48 \mathrm{~g})\right]$ plus $10 \mathrm{~mL}$ of concentrated sulphuric acid was added to the flasks and incubated overnight. The flasks were placed in the Kjeldahl digestion unit set at $100{ }^{\circ} \mathrm{C}$ for $20 \mathrm{~min}$, to digest the mixture followed by adjusting the volume to $100 \mathrm{~mL}$ with distilled water.

\subsubsection{Nitrogen}

The analysis of nitrogen was done by the Kjeldahl method [27]. An aliquot of $10 \mathrm{~mL}$ (of the aforementioned sample) was transferred to a distillation flask (100 mL) and $10 \mathrm{~mL}$ of $40 \% \mathrm{NaOH}$ was added to it. Boric acid was mixed with indicator solution (3 drops) and was kept at the receiving end of the condenser outlet, so that outlet dips in Boric acid. Distillation was carried out by passing the steam into a distillation flask and the color of the solution (boric acid + indicator) changes from reddish-purple to green, and after some time, all the ammonia $\left(\mathrm{NH}_{3}\right)$ was released from the distillation of the sample. After distillation, titration of the sample was carried out against $0.01 \mathrm{~N} \mathrm{H}_{2} \mathrm{SO}_{4}$ until the green color changed into purple. A blank (without plant sample) was also used to assess the contamination.

\subsubsection{Calcium}

Calcium estimation was conducted by titration with EDTA [28]. A $20 \mathrm{~mL}$ aliquot of the sample was transferred into a $100 \mathrm{~mL}$ Erlenmeyer flask and diluted with $20 \mathrm{~mL}$ of distilled water, followed by the addition of sodium hydroxide $(2 \mathrm{~N}, 2 \mathrm{~mL})$, and ammonium 
purpurate indicator $(50 \mathrm{mg})$. Then, titration was performed with EDTA $(0.01 \mathrm{~N})$. The color changed from red to purple. A blank (without plant sample) was also used in the same way.

\subsubsection{Carbon}

Carbon estimation was carried out by the protocol of Nelson and Sommers [29]. Leaf powder $(1 \mathrm{gm})$ of each variety of $M$. oleifera was transferred into a $500 \mathrm{~mL}$ conical flask, containing $\mathrm{K}_{2} \mathrm{Cr}_{2} \mathrm{O}_{7}(1 \mathrm{~N}, 10 \mathrm{~mL})$, followed by the addition of $\mathrm{H}_{2} \mathrm{SO}_{4}(20 \mathrm{~mL}$ concentrated) to it. The solution was incubated for $1 / 2 \mathrm{~h}$ followed by the addition of orthophosphoric acid $(10 \mathrm{~mL})$, and diphenylamine indicator $(1 \mathrm{~mL})$. Finally, the titration was performed against $(0.05 \mathrm{~N})$ ferrous ammonium sulphate (139 $\mathrm{g}$ of ferrous ammonium sulphate and $15 \mathrm{~mL}$ of concentrated $\mathrm{H}_{2} \mathrm{SO}_{4}$ ).

\subsubsection{Sodium and Potassium}

The $\mathrm{Na}$ and $\mathrm{K}$ contents were estimated using a flame photometer, as per the protocol of Gloterman et al. [30] and Sahrawat et al. [31]. Aliquots of MLEs (1 mL) were transferred into the volumetric flasks $(50 \mathrm{~mL})$, and a final volume of $50 \mathrm{~mL}$ was made with the distilled water. Finally, the solutions were subjected to flame photometer analysis, which was pre-adjusted with the standard solutions (1000 ppm stock solution and 5, 10, 15, 20, and $25 \mathrm{ppm}$ working solution) of sodium $(\mathrm{NaCl})$ and potassium $(\mathrm{KCl})$. Flame photometer readings of standards were plotted to obtain a standard curve.

\subsubsection{Sulphur}

Estimation of sulphur was performed by the protocol of Mottershead [32]. MLEs (1 mL each) were transferred into the respective volumetric flasks $(50 \mathrm{~mL})$, volumes were made up to $50 \mathrm{~mL}$ with distilled water and the transmittance at $470 \mathrm{~nm}$ was read spectrophotometrically. Meanwhile, 5, 10, 15, 20, and $25 \mathrm{~mL}$ of $100 \mathrm{ppm}$ sulphur standard was prepared in $250 \mathrm{~mL}$ volumetric flasks, followed by the addition of buffer salt solution $(25 \mathrm{~mL})$ and deionized water to make up the volume to $250 \mathrm{~mL}$. Ten milliliters of solution from each flask was transferred to $50 \mathrm{~mL}$-capacity volumetric flasks, followed by the addition of $1 \mathrm{~mL}$ $\mathrm{HCl}(6 \mathrm{~N})$ and $0.5 \mathrm{~g}$ of barium chloride crystals. The flasks were left undisturbed and the final volume was made up to $50 \mathrm{~mL}$ with distilled water. Thereafter, the transmittance at $470 \mathrm{~nm}$ was recorded using a spectrophotometer and the standard curve was drawn with the transmittance values.

\subsubsection{Phosphorous}

Phosphorous was estimated by the vanadate-molybdate method of Piper [33]. An aliquot of five different MLE samples was transferred to $25 \mathrm{~mL}$ volumetric flasks. A few drops of 2,4-dinitrophenol indicator and $\mathrm{Na}_{2} \mathrm{CO}_{3}(4 \mathrm{~N})$ were added to it until the yellow color disappeared. The $\mathrm{pH}$ was adjusted to 4.8 with $\mathrm{HCl}(6 \mathrm{~N}, 2 \mathrm{~mL})$. Thereafter, $5 \mathrm{~mL}$ vanadate-molybdate reagent was added and deionized water was added to make up the volume to $25 \mathrm{~mL}$. Transmittance was read at $470 \mathrm{~nm}$ after $30 \mathrm{~min}$ incubation (as the color starts to develop). Meanwhile, 5, 10, 15, 20, and $25 \mathrm{~mL}$ of $100 \mathrm{ppm}$ of the phosphorous standard was transferred to the $25 \mathrm{~mL}$ volumetric flasks and the same procedure was followed as mentioned above. Transmittance was read at $470 \mathrm{~nm}$ and the standard curve was drawn.

\subsection{FRAP Assay}

For ferric-reducing antioxidant power (FRAP) activity, leaf powder ( $5 \mathrm{~g}$ ) of five different varieties of $M$. oleifera were suspended in $100 \mathrm{~mL}$ of ethanol in respective conical flasks. Thereafter, the flasks were placed on a rotatory shaker $(200 \mathrm{rpm})$, set at $30{ }^{\circ} \mathrm{C}$ for $48 \mathrm{~h}$. The MLE was evaporated in the evaporator shaker and was collected in labeled vials for further use. To the different concentrations of MLE (10-40 $\mu \mathrm{g} / \mathrm{mL})$ of each variety, $625 \mu \mathrm{L}$ of $\mathrm{Na}_{2} \mathrm{PO}_{4}$ buffer ( $\mathrm{pH}$ 7.4) plus $625 \mu \mathrm{L}$ of potassium ferricyanide were added and the mixture was incubated for $20 \mathrm{~min}$ at $50{ }^{\circ} \mathrm{C}$. The mixture was allowed to cool and then 
$625 \mu \mathrm{L}$ of trichloroacetic acid (TCA) was added. The mixture was centrifuged at $2000 \mathrm{rpm}$ for $10 \mathrm{~min}$. To the supernatant, $625 \mu \mathrm{L}$ distilled water plus $125 \mu \mathrm{L} \mathrm{FeCl}_{3}$ were mixed, and absorbance was recorded spectrophotometrically at $700 \mathrm{~nm}$ [34].

\subsection{HPLC Analysis}

High-Performance Liquid Chromatography (HPLC) of the MLEs of five different varieties was performed using an Agilent-1260 system, Germany. The system is equipped with a quaternary pump, VWD UV detector, column C18 (250 L $\times 4.6$ I.D.mm; $5 \mu \mathrm{m}$ particle size; $100 \AA$ pore size), and an autosampler. The analytes were eluted with a gradient of methanol- $0.40 \%$ phosphoric acid (ratio $49: 51$ ), with a flow rate of $1 \mathrm{~mL} / \mathrm{min}$. Estimation of $\beta$-sitosterol, quercetin, kaempferol, and moringin contents was performed. Azur 5.0 software was deployed for data analysis [35]. The following formula was used for calculating the bioactive compound \% in the sample.

Area of sample/(Weight of sample) $\times$ Weight of standard/Area of standard $\times$ Dilution of sample $/$ (Dilution of standard) $\times \%$ Purity of the standard $=$ Bioactive compound $\%$ in sample.

\subsection{3-(4,5-dimethylthiazol-2-yl)-2,5-diphenyl Tetrazolium Bromide MTT Assay}

For MTT assay, the human liver cell line (HepG2) was procured from NCCS, Pune, India, and culture was maintained at Lovely Professional University, Punjab, India. The cells were grown in DMEM media (Gibco, USA), supplemented with fetal bovine serum $(10 \%)$, in a $\mathrm{CO}_{2}$ incubator set at $37^{\circ} \mathrm{C}$. Cytotoxicity evaluation was carried out according to the protocol provided by the American Type Culture Collection (ATCC) [36,37]. Cells were inoculated at a density of 20,000 cells in 96-well plates (Thermo delta surface) and were maintained in a humidified atmosphere [air $\left.(64 \%), \mathrm{CO}_{2}(5 \%)\right]$ at $37^{\circ} \mathrm{C}$. These cells were treated with different concentrations $(0.25,0.5,1,2,3,4$, and $5 \mathrm{mg} / \mathrm{mL})$ of MLEs. Thereafter, $50 \mu \mathrm{L}$ MTT solution [5 mg MTT dye dissolved in $1 \mathrm{~mL}$ PBS] was poured into each well and the plate was incubated for $4 \mathrm{~h}$ at $37^{\circ} \mathrm{C}$. After incubation, DMSO $(15 \mu \mathrm{L})$ was added into each well. The absorbance was recorded at $570 \mathrm{~nm}$ using an ELISA reader. Percentage cytotoxicity was calculated from the absorbance values using the formula given below:

$\%$ cell cytotoxicity $=100-[($ O.D. of sample - O.D. of blank $) /($ O.D. of control - O.D. of blank $)] \times 100$

\section{Results and Discussion}

\subsection{Total Sugar Content}

The total sugar content present in MLEs of five M. oleifera varieties was analyzed at the young stage (3-months-old) and mature stage (15-months-old). Maximum sugar content was recorded in Jaffna $(0.39 \pm 0.04$ and $0.51 \pm 0.01 \mu \mathrm{g} / \mathrm{mL})$ followed by PKM-1 $(0.25 \pm 0.001$ and $0.45 \pm 0.006 \mu \mathrm{g} / \mathrm{mL})$, PKM-2 $(0.12 \pm 0.001$ and $0.301 \pm 0.004 \mu \mathrm{g} / \mathrm{mL})$, ODC $(0.08 \pm 0.003$ and $0.16 \pm 0.01 \mu \mathrm{g} / \mathrm{mL})$ and Conventional $(0.05 \pm 0.002$ and $0.08 \pm 0.01 \mu \mathrm{g} / \mathrm{mL}$ ) (Figure 1A). Oxidation-reduction reactions are extremely important in maintaining proper health, by providing an energy source for the body. This process requires catalysts called reducing agents, oxidizing agents, or reducing sugars (glucose, fructose, lactose, and maltose). Sugars (fructose, galactose, glucose, sucrose, lactose, maltose, and raffinose) are the essential component of the human diet [22]. According to Berkovich et al., M. oleifera contain reducing sugars [38].

\subsection{Protein Content}

Among all the five varieties, Jaffna showed the highest values of protein content in comparison with the others. The trend observed for the total soluble protein in leaves was: Jaffna $(0.695 \pm 0.01$ and $0.94 \pm 0.01 \mu \mathrm{g} / \mathrm{mL})>$ PKM- $1(0.58 \pm 0.01$ and $0.88 \pm 0.01 \mu \mathrm{g} / \mathrm{mL})$ $>\mathrm{PKM}-2(0.57 \pm 0.004$ and $0.80 \pm 0.01 \mu \mathrm{g} / \mathrm{mL})>\mathrm{ODC}(0.44 \pm 0.005$ and $0.74 \pm 0.01 \mu \mathrm{g} / \mathrm{mL})$ $>$ conventional $(0.31 \pm 0.02$ and $0.64 \pm 0.01 \mu \mathrm{g} / \mathrm{mL}$ ) (Figure 1B). Sanchez-Machado et al. reported the protein content in Moringa plant parts to be $20.66 \%$ (immature pods), $30 \%$ 
(mature pods), and 31\% (flowers), respectively [39]. In our study, Jaffna was found to be a promising variety that can be used to cope with protein deficiency diseases such as kwashiorkor, marasmus, edema, weak immune system, muscle shrinking, impaired mental health, etc.
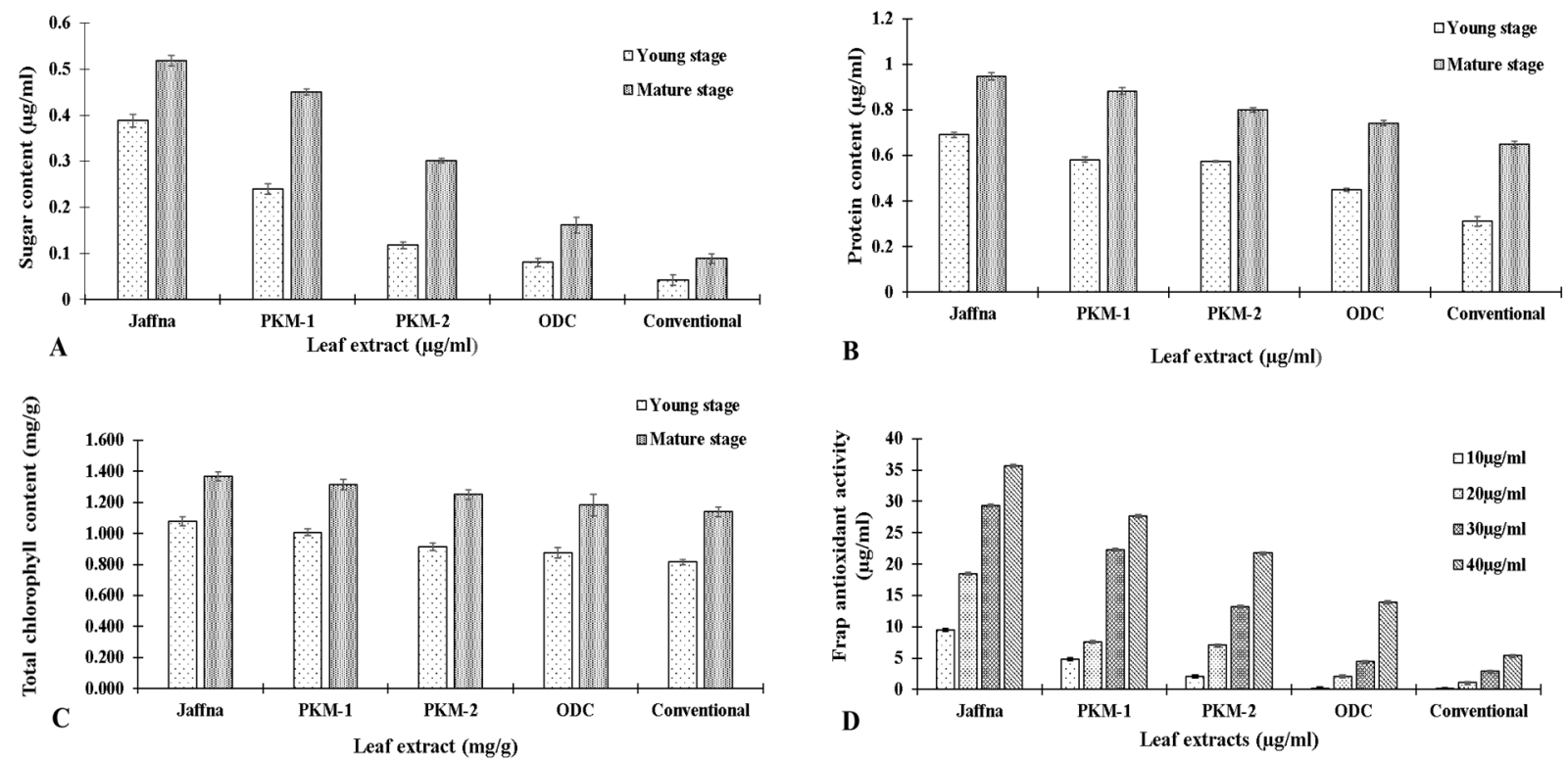

Figure 1. Estimation of biochemical characteristics of five different varieties of M. oleifera: (A) sugar content, (B) protein content, (C) total chlorophyll content, and (D) FRAP antioxidant activity.

\subsection{Chlorophyll Content}

The chlorophyll molecules are the main pigments which absorb the light in the photosystem reaction centers for photochemical reactions. Chlorophylls are known to have several therapeutic properties (anti-carcinogenic, anti-bacterial, anti-inflammatory, deodorizing, and wound healing activities) [40,41]. In our study M. oleifera varieties at two different stages of plant growth (young stage: 3-months-old and mature stage: 15 -months-old) were assessed to estimate the amount of chlorophyll a, chlorophyll $\mathrm{b}$ and total chlorophyll content. Jaffna variety exhibited the highest chlorophyll content at all the stages. The trend observed was: Jaffna $(1.31,1.18$ and $0.82 \mathrm{mg} / \mathrm{g})>$ PKM-1 $(1.14,1.02$ and $0.68 \mathrm{mg} / \mathrm{g})>$ PKM-2 $(0.96,0.83$ and $0.59 \mathrm{mg} / \mathrm{g})>\mathrm{ODC}(0.86,0.70$ and $0.49 \mathrm{mg} / \mathrm{g})>$ conventional $(0.68$, 0.58 and $0.30 \mathrm{mg} / \mathrm{g}$ ) (Figure $1 \mathrm{C}$ ).

\subsection{Mineral Content}

Mineral contents in the five different varieties of $M$. oleifera were estimated by using a flame photometer ( $\mathrm{Na}$ and $\mathrm{K})$, spectrophotometer (P, and $\mathrm{S})$, Kjeldahl method $(\mathrm{N})$, and titration ( $\mathrm{Ca}$ and $\mathrm{C})$ as shown in Table 1. Jaffna exhibited the highest mineral content (Na: $10.98 \%$, K: $15.14 \%$, P: $1.11 \%$, S: $1.13 \%$, Ca: $5.9 \%, \mathrm{~N}: 2.32 \%$ and C: $5.7 \%$ ) followed by PKM-1, PKM-2, ODC, and conventional. The mineral content in other varieties (PKM-1, PKM-2, ODC, and conventional) were significantly lowered compared with the Jaffna as clearly presented in Table 1 . It can be concluded that the Jaffna variety M. oleifera is the most nutrient-rich variety, among the five. It contains macro-essential minerals such as $\mathrm{Na}$, $\mathrm{K}, \mathrm{Ca}, \mathrm{N}, \mathrm{S}, \mathrm{C}$, and $\mathrm{P}$ which make it a potential source of food and is suitable to combat malnutrition. Our results are in agreement with that of Sodamade et al., Oluwole et al., and El Sohaimy et al. [42-44]. Jaffna leaves contain a high level of $\mathrm{K}$ and $\mathrm{Na}(15.14 \pm 0.1$ and $10.98 \pm 0.1 \%$ ), respectively. $\mathrm{K}$ works with $\mathrm{Na}$ (important electrolytes) and helps in maintaining the water balance and blood pressure. It also prevents heart diseases, osteoporosis, and kidney stones of the body [45]. In the case of plants, K also plays a key role in regulating enzymatic activities; providing strength against drought and stress, and 
in translocation of photosynthetic products between plant tissues [46]. As per the study of Ghosh et al. [47], our results with regard to the mineral content of $M$. oleifera varieties are also in consonance with the WHO dietary recommendation limits (data not shown).

Table 1. Percent mineral content of five Moringa oleifera varieties.

\begin{tabular}{cccccc}
\hline Mineral & Jaffna (a) & PKM-1 (b) & PKM-2 (c) & ODC (d) & Conventional (e) \\
\hline K & $15.14 \pm 1.1$ & $11.07 \pm 1 \mathrm{a}^{*}$ & $8.50 \pm 1 \mathrm{a}^{* *} \mathrm{~b}^{*}$ & $6.77 \pm 1 \mathrm{a}^{* *} \mathrm{~b}^{*}$ & $4.94 \pm 0.5 \mathrm{a}^{* *} \mathrm{~b}^{* *} \mathrm{c}^{*}$ \\
$\mathrm{Na}$ & $10.98 \pm 1$ & $9.77 \pm 1$ & $8.90 \pm 1$ & $7.70 \pm 1 \mathrm{a}^{*}$ & $6.61 \pm 1 \mathrm{a}^{*} \mathrm{~b}^{*}$ \\
$\mathrm{Ca}$ & $5.90 \pm 0.2$ & $4.96 \pm 0.2 \mathrm{a}^{*}$ & $3.96 \pm 0.3 \mathrm{a}^{* *} \mathrm{~b}^{* *}$ & $3.02 \pm 0.1 \mathrm{a}^{*} \mathrm{~b}^{* *} \mathrm{c}^{*}$ & $2.32 \pm 0.1 \mathrm{~b}^{* *} \mathrm{c}^{* *} \mathrm{~d}^{*}$ \\
$\mathrm{C}$ & $5.70 \pm 0.1$ & $4.99 \pm 0.1 \mathrm{a}^{* *}$ & $4.17 \pm 0.1 \mathrm{a}^{*} \mathrm{~b}^{* *}$ & $3.79 \pm 0.1 \mathrm{~b}^{* *} \mathrm{c}^{*}$ & $2.89 \pm 0.1 \mathrm{c}^{* *} \mathrm{~d}^{* *}$ \\
$\mathrm{~N}$ & $2.32 \pm 0.1$ & $2.08 \pm 0.1$ & $1.68 \pm 0.1 \mathrm{a}^{* *} \mathrm{~b}^{*}$ & $1.34 \pm 0.1 \mathrm{a}^{* *} \mathrm{~b}^{* *} \mathrm{c}^{*}$ & $0.99 \pm 0.1 \mathrm{a}^{* *} \mathrm{~b}^{* *} \mathrm{c}^{* *} \mathrm{~d}^{*}$ \\
$\mathrm{P}$ & $1.11 \pm 0.08$ & $0.86 \pm 0.02 \mathrm{a}^{* *}$ & $0.78 \pm 0.05 \mathrm{a}^{* *}$ & $0.63 \pm 0.04 \mathrm{a}^{* *} \mathrm{~b}^{*} \mathrm{c}^{*}$ & $0.51 \pm 0.02 \mathrm{a}^{* *} \mathrm{~b}^{* *} \mathrm{c}^{* *}$ \\
$\mathrm{~S}$ & $1.13 \pm 0.09$ & $0.84 \pm 0.03 \mathrm{a}^{*}$ & $0.76 \pm 0.05 \mathrm{a}^{* *}$ & $0.58 \pm 0.06 \mathrm{a}^{* *} \mathrm{~b}^{*}$ & $0.43 \pm 0.06 \mathrm{a}^{* *} \mathrm{~b}^{* *} \mathrm{c}^{* *}$ \\
\hline
\end{tabular}

Data were analyzed using one way ANOVA and Tukey's HSD post-hoc test. Levels of significance were represented in the form of (b-e) $\left.p<0.001\left(^{* *}\right),(\mathrm{b}-\mathrm{e}) p<0.05{ }^{*}\right)$ when compared with Jaffna (a) group.

\subsection{Frap Antioxidant Activity}

The present study demonstrated the antioxidant potential of five different varieties of Moringa oleifera, by using FRAP method $[48,49]$. The results of the study revealed that MLE of Jaffna variety possess high antioxidant property, followed by other four varieties. The trend of the scavenging activity was Jaffna $(9.47 \mu \mathrm{g} / \mathrm{mL}, 18.48 \mu \mathrm{g} / \mathrm{mL}$, and $29.39 \mu \mathrm{g} / \mathrm{mL})>$ PKM-1 $(4.82 \mu \mathrm{g} / \mathrm{mL}, 7.63 \mu \mathrm{g} / \mathrm{mL}$, and $22.33 \mu \mathrm{g} / \mathrm{mL})>$ PKM-2 $(2.10 \mu \mathrm{g} / \mathrm{mL}, 7.04 \mu \mathrm{g} / \mathrm{mL}$ and $13.18 \mu \mathrm{g} / \mathrm{mL})>$ ODC $(0.17 \mu \mathrm{g} / \mathrm{mL}, 2.10 \mu \mathrm{g} / \mathrm{mL}$, and $4.41 \mu \mathrm{g} / \mathrm{mL})>$ conventional $(0.05 \mu \mathrm{g} / \mathrm{mL}, 1.08 \mu \mathrm{g} / \mathrm{mL}$, and $2.86 \mu \mathrm{g} / \mathrm{mL}$ ) (Figure 1D). All the samples showed ferricreducing antioxidant capacity at a concentration dependent manner. Our results are in consonance with the earlier reports which state that flavonoids and phenols are directly responsible for antioxidant activity [35,50-53].

\subsection{HPLC Analysis}

To validate these findings, the MLEs of all five varieties of $M$. oleifera were subjected to HPLC for the quantification of four marker bioactive compounds: $\beta$-sitosterol, quercetin, kaempferol and moringin. It was found that the Jaffna variety showed the highest $\beta$ sitosterol $(0.244 \%)$, quercetin $(0.216 \%)$, kaempferol $(0.013 \%)$, and moringin $(0.063 \%)$ content, followed by PKM-1 [ $\beta$-sitosterol $(0.236 \%)$, quercetin $(0.154 \%)$, kaempferol $(0.012 \%)$, and moringin $(0.057 \%)$ ], PKM-2 [ $\beta$-sitosterol $(0.204 \%)$, quercetin $(0.127 \%)$, kaempferol $(0.004 \%)$, and moringin $(0.46 \%)]$, ODC [ $\beta$-sitosterol $(0.110 \%)$, quercetin $(0.073 \%)$, kaempferol $(0.002 \%)$, and moringin $(0.43 \%)]$, and conventional $[\beta$-sitosterol $(0.056 \%)$, quercetin $(0.030 \%)$, kaempferol $(0.001 \%)$, and moringin $(0.035 \%)]$ (Supplementary Figure S1a-d, Table 2 and Figure 2).

Table 2. HPLC analysis of selected compounds reported in MLEs.

\begin{tabular}{ccccccccc}
\hline \multirow{2}{*}{ Variety } & \multicolumn{7}{c}{ Quantified Compound } \\
\cline { 2 - 8 } & \multicolumn{2}{c}{$\beta$-Sitosterol } & \multicolumn{2}{c}{ Quercetin } & \multicolumn{2}{c}{ Kaempferol } & \multicolumn{2}{c}{ Moringin } \\
\cline { 2 - 8 } & Area & \% Content & Area & \% Content & Area & \% Content & Area & \% Content \\
\hline Jaffna & 154,084 & 0.244 & 355,765 & 0.216 & 663,751 & 0.013 & $1,254,800$ & 0.063 \\
PKM-1 & 149,743 & 0.236 & 234,489 & 0.155 & 652,556 & 0.012 & $1,133,682$ & 0.057 \\
PKM-2 & 129,271 & 0.204 & 204,488 & 0.127 & 239,864 & 0.004 & 898,404 & 0.046 \\
ODC & 72,338 & 0.110 & 118,729 & 0.073 & 111,264 & 0.002 & 864,931 & 0.043 \\
Conventional & 35,945 & 0.056 & 94,796 & 0.030 & 71,290 & 0.001 & 671,978 & 0.03 \\
\hline
\end{tabular}

The present study showed that the different varieties of $M$. oleifera contain sufficient amounts of the aforementioned anti-cancer compounds. The obtained results are in consonance with the findings of Fahey [54], who reported the presence of phytochemicals 
(zeatin, caffeoylquinic acid, kaempferitrin, isoquercitin, rhamnetin, rhamnose, glucosinolates, and isothiocyanates) in the same plant. Likewise, HPLC and MS analysis performed by Singh et al. [55], showed the presence of chlorogenic acid, vanillin, gallic acid, ferulic acid, and ellagic acid in seeds, fruits, and leaves of M. oleifera. Farooq Anwar et al. have also reported that the leaves of $\mathrm{M}$. oleifera contain unique compounds such as o-coumaric acid, epicatechin, niazirinin, niaziminin A, niazirin, 4-[(4'-O-acetyl-L rhamnosyloxy) benzyl] isothiocyanate, 3-caffeoylquinic, and 5-caffeoylquinic acid [56]. A non-exhaustive list of phytochemicals reported in M. oleifera is shown in Supplementary Table S3. The comparison between the five varieties of M. oleifera indicates that the Jaffna variety is endowed with a higher content of anti-cancer compounds than the other four. Thus, these results suggest the cultivation and consumption of Jaffna leaves in cancer-affected zones worldwide.

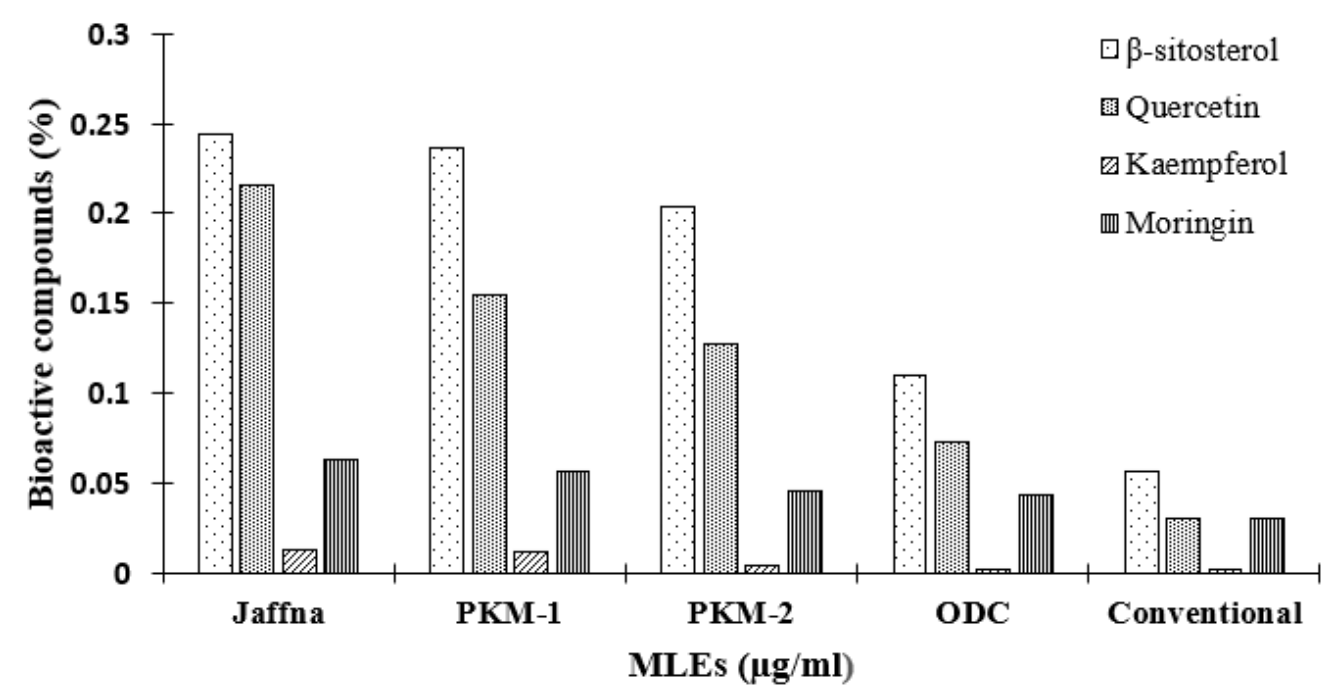

Figure 2. HPLC analysis of the selected anti-cancer compounds reported in MLEs.

\subsection{MTT Assay}

MLEs of all five varieties were also evaluated for their cytotoxic activity against the HepG2 cancer cell line, through the MTT assay. Figure 2 reveals the percentage (\%) cytotoxicity of different concentrations of the MLEs $(0.25,0.5,1,2,3,4$, and $5 \mathrm{mg} / \mathrm{mL})$ of five varieties. MLEs of all varieties exhibited dose-dependent cytotoxic activity against the cancer cell line, which were found to be significant. 5-Fluorouracil was used as a standard $(0.5,0.1,0.2,0.3,0.4,0.5$ and $0.6 \mathrm{mM})$. The IC50 value of $5-\mathrm{FU}$ was $0.87 \mathrm{mM} / \mathrm{mL}$. The trend observed for cytotoxicity on the basis of IC50 values was: conventional $(1.22 \mathrm{mg} / \mathrm{mL})>$ ODC $(0.90 \mathrm{mg} / \mathrm{mL})>$ PKM-2 $(0.65 \mathrm{mg} / \mathrm{mL})>$ PKM-1 $(0.35 \mathrm{mg} / \mathrm{mL})>$ Jaffna $(0.15 \mathrm{mg} / \mathrm{mL})$. Jaffna leaf extract showed a strong cytotoxic activity as compared to the other four varieties (Table 3 and Figure 3). Thus, it can be used as a novel alternative and complementary therapeutic agent against cancer treatment regimes.

Table 3. MTT assay using MLEs of five varieties of Moringa oleifera.

\begin{tabular}{|c|c|c|c|c|c|c|c|c|c|}
\hline \multirow[b]{2}{*}{ Varieties } & \multicolumn{7}{|c|}{ Cytotoxicity at Different Concentrations $(\mathrm{mg} / \mathrm{mL})$} & \multirow[b]{2}{*}{$p$ Value } & \multirow[b]{2}{*}{$\begin{array}{c}\mathrm{IC} 50 \\
(\mathrm{mg} / \mathrm{mL})\end{array}$} \\
\hline & 0.25 & 0.5 & 1 & 2 & 3 & 4 & 5 & & \\
\hline Jaffna & $48.37 \pm 0.001$ & $56.97 \pm 0.002$ & $63.86 \pm 0.001$ & $67.01 \pm 0.003$ & $68.64 \pm 0.009$ & $72.27 \pm 0.008$ & $74.28 \pm 0.021$ & $p<0.001$ & 0.15 \\
\hline PKM-1 & $43.97 \pm 0.001$ & $45.94 \pm 0.003$ & $48.66 \pm 0.004$ & $50.38 \pm 0.004$ & $60.2 \pm 0.007$ & $67.20 \pm 0.004$ & $71.22 \pm 0.004$ & $p<0.001$ & 0.35 \\
\hline PKM-2 & $36.13 \pm 0.046$ & $40.63 \pm 0.002$ & $46.94 \pm 0.004$ & $48.66 \pm 0.004$ & $53.25 \pm 0.003$ & $63.09 \pm 0.001$ & $68.64 \pm 0.025$ & $p<0.001$ & 0.65 \\
\hline ODC & $27.53 \pm 0.005$ & $35.37 \pm 0.007$ & $41.49 \pm 0.001$ & $46.36 \pm 0.004$ & $52.10 \pm 0.001$ & $60.80 \pm 0.003$ & $63.19 \pm 0.008$ & $p<0.001$ & 0.90 \\
\hline Conventional & $22.37 \pm 0.014$ & $32.31 \pm 0.009$ & $35.37 \pm 0.007$ & $40.63 \pm 0.002$ & $51.62 \pm 0.008$ & $54.58 \pm 0.002$ & $57.83 \pm 0.002$ & $p<0.001$ & 1.22 \\
\hline
\end{tabular}

IC50 value of 5-FU (standard): $0.87 \mathrm{mM} / \mathrm{mL}$. Data were analyzed using one-way ANOVA, Levels of significance were represented in the form of $p<0.001$ when compared with and between groups. 


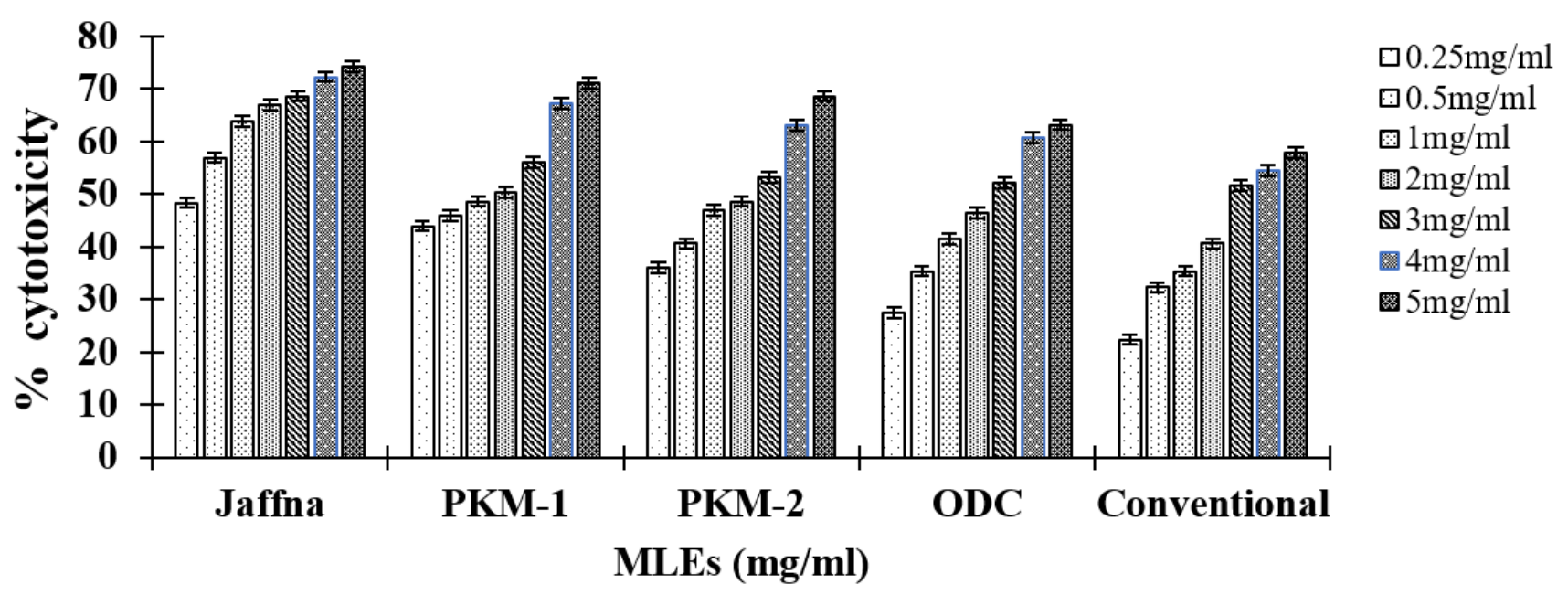

Figure 3. Graphical representation of MTT assay using MLEs.

Cancer cells possess tremendous potential to divide and therefore anticancer agents are required to stop their growth by targeting them. Interestingly, MLE performs a wide range of biological activities and even targets several proteins and biomolecules to retard cancer progression $[57,58]$. It contains glucosinolates that have the ability to induce apoptosis and are very effective against cancer [59]. Berkovich et al. reported that MLE inhibits pancreatic cancer cell growth [38]; Thorneloe et al.-breast cancer cell growth [60] and Sadek et al. [11] - liver cancer (induced by diethylnitrosamine in rats). M. oleifera also inhibits the cell viability of liver carcinoma, lymphoblastic, and myeloid leukemia [61]. These activities of Moringa can be attributed to the presence of different classes of anticancer compounds such as kaempferol, niazimicin, $\beta$-sitosterol-3-O- $\beta$-D-glucopyranoside, and 4-( $\alpha$-L-rhamnosyloxy) benzyl isothiocyanate [59]. These target the cell cycle by accumulating the cells at the sub-G1 phase. According to Tiloke et al., hot water MLE exhibits antiproliferative activity against A549 lung cancer cells [57]. The reason behind this is that it increases reactive oxygen species (ROS), which leads to the induction of caspases, cleavage of PARP-1, and P53 initiates apoptosis of cancer cells. MLE up-regulates apoptotic markers which leads to the death of cancer cells and down-regulates the NFKB pathway which further decreases the expression of P-IKB $\alpha, \operatorname{IKB} \alpha$, and P65 proteins. Together, these induce cytotoxicity in cancer cells [62]. The present study reports the cytotoxic potential of five different varieties of $M$. oleifera on the HepG2 cell line. Jaffna variety showed the highest cytotoxic effect on cancer the cell line as compared to the other varieties.

\section{Conclusions}

The easiest solution for affordable health and nutrition is to shake hands with nature. As mentioned, mother nature has provided mankind with the gift of 'superfood trees' (known as M. oleifera) to combat malnutrition. The fact that Moringa is a source of nutrition and medicine has been tested over time and is deeply rooted in Ayurveda, Siddha, Unani, and the traditional Chinese system of medicine (TCM). It is interesting to note that people of all age groups can consume moringa leaf powder and can replenish vitamins and minerals. The present study shows the comparison of biochemical properties of PKM-1, PKM-2, ODC, Jaffna, and conventional varieties of $M$. oleifera on the basis of different parameters: Frap antioxidant activity, sugar, protein and mineral contents, percentage of phytochemicals (four anticancer compounds), and cytotoxicity against the HepG2 cell line. By assessing these parameters, it was possible to conclude that the Jaffna variety is the most beneficial variety in terms of nutrition, anticancer bioactive compounds, and cytotoxic activity. However, the Jaffna variety needs to be explored further to be involved in reforestation programs so that many people may fully capitalize on its amazing benefits. Thus, meticulous studies on other nutritional and medicinal parameters of Jaffna should 
be conducted to explore its potential as an alternative and cost-effective source of nutrition and medicine, for better healthcare.

Supplementary Materials: The following are available online at https:/ /www.mdpi.com/article/10 .3390/plants10112348/s1, Figure S1: (a) HPLC chromatogram for estimation of $\beta$-sitosterol content in M.oleifera varieties leaf extracts. [A] standard compound [B] Jaffna [C] PKM-1 [D] PKM-2 [F] ODC and [F] Conventional. (b) HPLC chromatogram for estimation of Quercitin content in M. oleifera varieties leaf extracts. [A] Standard compound [B] Jaffna, [C] PKM-1 [D] PKM-2 [F] ODC and [F] Conventional. (c) HPLC chromatogram for estimation of Kaempferol content in M.oleifera varieties leaf extracts. [A] Standard compound [B] Jaffna [C] PKM-1, [D] PKM-2 [F] ODC and [F] Conventional. (d) HPLC chromatogram for estimation of Moringin content in M. oleifera varieties leaf extracts. [A] Standard compound [B] Jaffna [C] PKM-1 [D] PKM-2 [F] ODC and [F] Conventional, Table S1: Anti-bacterial activity (bacterial zone of inhibition values) of $M$. oleifera varieties, Table S2: Plant growth promoting activity of $M$. oleifera varieties leaf extract on S. rebaudiana, Table S3: Phytochemical constituents reported in different parts of Moringa oleifera.

Author Contributions: Conceptualization, B.K. and B.F.; methodology, B.F. and D.M.; software, D.Y.; validation, B.K., and D.Y.; formal analysis, B.K.; investigation, B.F.; resources, B.K.; data curation, D.Y.; writing—original draft preparation, B.K. and B.F.; writing—review and editing, B.K. and D.Y.; visualization, D.Y.; supervision, B.K.; project administration, B.K.; funding acquisition, B.K. and D.Y. All authors have read and agreed to the published version of the manuscript.

Funding: This work was supported by the National Research Foundation of Korea (NRF) funded by the Ministry of Education (NRF-2019R1G1A1008566).

Institutional Review Board Statement: Not applicable.

Informed Consent Statement: Not applicable.

Data Availability Statement: The data presented in this study are available upon request from the corresponding author.

Acknowledgments: The authors are thankful to Lovely Professional University (LPU), Punjab, India for the infrastructural support.

Conflicts of Interest: The authors declare no conflict of interest.

\section{References}

1. Ayerza, R. Seed characteristics, oil content and fatty acid composition of moringa (Moringa oleifera Lam.) seeds from three arid land locations in Ecuador. Ind. Crop. Prod. 2019, 140, 111575. [CrossRef]

2. Boopathi, N.M.; Raveendran, M.; Kole, C. The Moringa Genome; Springer: Cham, Switzerland, 2021; p. 185. [CrossRef]

3. Mahmood, K.T.; Mugal, T.; Haq, I.U. Moringa oleifera: A natural gift-A review. J. Pharm. Sci. Res. 2010, 2, 775.

4. Ayerza, R. Seed yield components, oil content, and fatty acid composition of two cultivars of moringa (Moringa oleifera Lam.) growing in the Arid Chaco of Argentina. Ind. Crop. Prod. 2011, 33, 389-394. [CrossRef]

5. Saini, R.K.; Sivanesan, I.; Keum, Y.-S. Phytochemicals of Moringa oleifera: A review of their nutritional, therapeutic and industrial significance. 3 Biotech 2016, 6, 203. [CrossRef]

6. Oyeyinka, A.T.; Oyeyinka, S.A. Moringa oleifera as a food fortificant: Recent trends and prospects. J. Saudi Soc. Agric. Sci. 2018, 17, 127-136. [CrossRef]

7. Nambiar, R.B.; Sellamuthu, P.S.; Perumal, A.B. Microencapsulation of tender coconut water by spray drying: Effect of Moringa oleifera gum, maltodextrin concentrations, and inlet temperature on powder qualities. Food Bioproc. Technol. 2017, 10, 1668-1684. [CrossRef]

8. Premi, M.; Sharma, H. Effect of different combinations of maltodextrin, gum arabic and whey protein concentrate on the encapsulation behavior and oxidative stability of spray dried drumstick (Moringa oleifera) oil. Int. J. Biol. Macromol. 2017, 105, 1232-1240. [CrossRef] [PubMed]

9. Farooq, B.; Koul, B. Comparative analysis of the antioxidant, antibacterial and plant growth promoting potential of five Indian varieties of Moringa oleifera L. S. Afr. J. Bot. 2020, 129, 47-55. [CrossRef]

10. Padayachee, B.; Baijnath, H. An updated comprehensive review of the medicinal, phytochemical and pharmacological properties of Moringa oleifera. S. Afr. J. Bot. 2020, 129, 304-316. [CrossRef]

11. Sadek, K. Chemotherapeutic efficacy of an ethanolic M oringa oleifera leaf extract against chromium-induced testicular toxicity in rats. Andrologia 2014, 46, 1047-1054. [CrossRef] [PubMed]

12. Stohs, S.J.; Hartman, M.J. Review of the safety and efficacy of Moringa oleifera. Phytother. Res. 2015, 29, 796-804. [CrossRef] [PubMed] 
13. Metwally, F.M.; Rashad, H.M.; Ahmed, H.H.; Mahmoud, A.A.; Raouf, E.R.A.; Abdalla, A.M. Molecular mechanisms of the anti-obesity potential effect of Moringa oleifera in the experimental model. Asian Pac. J. Trop. Biomed. 2017, 7, 214-221. [CrossRef]

14. Bhatnagar, A.; Krishna, A.G. Natural antioxidants of the Jaffna variety of Moringa oleifera seed oil of Indian origin as compared to other vegetable oils. Grasas Y Aceites 2013, 64, 537-545.

15. Jain, P.; Farooq, B.; Lamba, S.; Koul, B. Foliar spray of Moringa oleifera Lam. leaf extracts (MLE) enhances the stevioside, zeatin and mineral contents in Stevia rebaudiana Betoni. S. Afr. J. Bot. 2020, 132, 249-257. [CrossRef]

16. Koul, B.; Chase, N. Moringa oleifera Lam.: Panacea to several maladies. J. Chem. Pharm. Res. 2015, 7, 687-707.

17. Azad, A.K.; Rasul, M.; Khan, M.M.K.; Sharma, S.C.; Islam, R. Prospect of Moringa seed oil as a sustainable biodiesel fuel in Australia: A review. Procedia Eng. 2015, 105, 601-606. [CrossRef]

18. Camacho, F.P.; Sousa, V.S.; Bergamasco, R.; Teixeira, M.R. The use of Moringa oleifera as a natural coagulant in surface water treatment. Chem. Eng. J. 2017, 313, 226-237. [CrossRef]

19. Trigo, C.; Castello, M.L.; Ortola, M.D.; Garcia-Mares, F.J.; Desamparados Soriano, M. Moringa oleifera: An unknown crop in developed countries with great potential for industry and adapted to climate change. Foods 2021, 10, 31. [CrossRef]

20. Shi, S.; Guo, K.; Tong, R.; Liu, Y.; Tong, C.; Peng, M. Online extraction-HPLC-FRAP system for direct identification of antioxidants from solid Du-zhong brick tea. Food Chem. 2019, 288, 215-220. [CrossRef]

21. Dubois, M. Use of phenol reagent for the determination of total sugar. Anal. Chem. 1956, 28, 350. [CrossRef]

22. Fu, X.; Wang, X.; Rao, X. An LED-based spectrally tuneable light source for visible and near-infrared spectroscopy analysis: A case study for sugar content estimation of citrus. Biosyst. Eng. 2017, 163, 87-93. [CrossRef]

23. Lowry, O.H.; Rosebrough, N.J.; Farr, A.L.; Randall, R.J. Protein measurement with the Folin phenol reagent. J. Biol. Chem. 1951, 193, 265-275. [CrossRef]

24. Mattoo, R.L.; Ishaq, M.; Saleemuddin, M. Protein assay by Coomassie brilliant blue G-250-binding method is unsuitable for plant tissues rich in phenols and phenolases. Anal. Biochem. 1987, 163, 376-384. [CrossRef]

25. Folin, O.; Ciocalteu, V. On tyrosine and tryptophane determinations in proteins. J. Biol. Chem. 1927, 73, 627-650. [CrossRef]

26. Arnon, D.I. Copper enzymes in isolated chloroplasts. Polyphenoloxidase in Beta vulgaris. Plant Physiol. 1949, 24, 1. [CrossRef] [PubMed]

27. Kjeldahl, J. Neue Methode zur Bestimmung des Stickstoffs in Organischen Korpern. Z. Für Anal. Chem. 1883, 22, 366-382. [CrossRef]

28. Allison, L.E.; Richards, L.A. Diagnosis and Improvement of Saline and Alkali Soils; Soil and Water Conservative Research Branch, Agricultural Research Service; Salinity Laboratory: Washington, DC, USA, 1954.

29. Nelson, D.W.; Sommers, L.E. Total carbon, organic carbon, and organic matter. In Methods of Soil Analysis: Part 3 Chemical Methods; Soil Science Society of America, Inc.: Madison, WI, USA, 1996; Volume 5, pp. 961-1010.

30. Golterman, H.; Clymo, R.; Ohnstad, M. Methods for physical \& chemical analysis of fresh waters. In IBP Handbook No. 8-Blackwell Scientific Publications; Blackwell Science Inc.: Boston, MA, USA, 1978.

31. Sahrawat, K.; Kumar, G.R.; Murthy, K. Sulfuric acid-selenium digestion for multi-element analysis in a single plant digest. Commun. Soil Sci. Plant Anal. 2002, 33, 3757-3765. [CrossRef]

32. Mottershead, B. Estimation of sulphur in biological materials using the Technicon AutoAnalyser. Lab. Pract. 1971, $20,483-491$. [PubMed]

33. Piper, C. Vanado-Molybdo-Phosphoric Yellow Colour Method. Soil Plant Anal. 1966, 368.

34. Hammi, K.M.; Hammami, M.; Rihouey, C.; Le Cerf, D.; Ksouri, R.; Majdoub, H. Optimization extraction of polysaccharide from Tunisian Zizyphus lotus fruit by response surface methodology: Composition and antioxidant activity. Food Chem. 2016, 212, 476-484. [CrossRef]

35. Vongsak, B.; Sithisarn, P.; Gritsanapan, W. Simultaneous HPLC quantitative analysis of active compounds in leaves of Moringa oleifera Lam. J. Chromatogr. Sci. 2014, 52, 641-645. [CrossRef]

36. Cory, A.H.; Owen, T.C.; Barltrop, J.A.; Cory, J.G. Use of an aqueous soluble tetrazolium/formazan assay for cell growth assays in culture. Cancer Commun. 1991, 3, 207-212. [CrossRef] [PubMed]

37. Wilkening, S.; Stahl, F.; Bader, A. Comparison of primary human hepatocytes and hepatoma cell line Hepg2 with regard to their biotransformation properties. Drug Metab. Dispos. 2003, 31, 1035-1042. [CrossRef]

38. Berkovich, L.; Earon, G.; Ron, I.; Rimmon, A.; Vexler, A.; Lev-Ari, S. Moringa oleifera aqueous leaf extract down-regulates nuclear factor-kappaB and increases cytotoxic effect of chemotherapy in pancreatic cancer cells. BMC Complement. Altern. Med. 2013, 13, 212. [CrossRef]

39. Sánchez-Machado, D.I.; Núñez-Gastélum, J.A.; Reyes-Moreno, C.; Ramírez-Wong, B.; López-Cervantes, J. Nutritional quality of edible parts of Moringa oleifera. Food Anal. Methods 2010, 3, 175-180. [CrossRef]

40. Schoefs, B. Chlorophyll and carotenoid analysis in food products. Properties of the pigments and methods of analysis. Trends Food Sci. Technol. 2002, 13, 361-371. [CrossRef]

41. Kang, Y.-R.; Park, J.; Jung, S.K.; Chang, Y.H. Synthesis, characterization, and functional properties of chlorophylls, pheophytins, and Zn-pheophytins. Food Chem. 2018, 245, 943-950. [CrossRef]

42. Sodamade, A.; Bolaji, O.; Adeboye, O. Proximate analysis, mineral contents and functional properties of Moringa oleifera leaf protein concentrate. IOSR J. Appl. Chem. 2013, 4, 47-51. 
43. Ijarotimi, O.S.; Adeoti, O.A.; Ariyo, O. Comparative study on nutrient composition, phytochemical, and functional characteristics of raw, germinated, and fermented Moringa oleifera seed flour. Food Sci. Nutr. 2013, 1, 452-463. [CrossRef] [PubMed]

44. El Sohaimy, S.A.; Hamad, G.M.; Mohamed, S.E.; Amar, M.H.; Al-Hindi, R.R. Biochemical and functional properties of Moringa oleifera leaves and their potential as a functional food. Glob. Adv. Res. J. Agric. Sci. 2015, 4, 188-199.

45. Elson, M.; Haas, M. Role of potassium in maintaining health. Period. Paralys. Int. 2007, 21, 23.

46. Anjum, S.A.; Xie, X.-Y.; Wang, L.-C.; Saleem, M.F.; Man, C.; Lei, W. Morphological, physiological and biochemical responses of plants to drought stress. Afr. J. Agric. Res. 2011, 6, 2026-2032.

47. Ghosh, A.; Saleh-e-In, M.M.; Abukawsar, M.M.; Ahsan, M.A.; Rahim, M.M.; Bhuiyan, M.N.H.; Roy, S.K.; Naher, S. Characterization of quality and pharmacological assessment of Pimpinella anisum L.(Anise) seeds cultivars. J. Food Meas. Charact. 2019, 13, $2672-2685$.

48. Ou, B.; Huang, D.; Hampsch-Woodill, M.; Flanagan, J.A.; Deemer, E.K. Analysis of antioxidant activities of common vegetables employing oxygen radical absorbance capacity (ORAC) and ferric reducing antioxidant power (FRAP) assays: A comparative study. J. Agric. Food Chem. 2002, 50, 3122-3128. [CrossRef] [PubMed]

49. Prior, R.L.; Wu, X.; Schaich, K. Standardized methods for the determination of antioxidant capacity and phenolics in foods and dietary supplements. J. Agric. Food Chem. 2005, 53, 4290-4302. [CrossRef]

50. Heim, K.E.; Tagliaferro, A.R.; Bobilya, D.J. Flavonoid antioxidants: Chemistry, metabolism and structure-activity relationships. J. Nutr. Biochem. 2002, 13, 572-584. [CrossRef]

51. Soong, Y.-Y.; Barlow, P.J. Antioxidant activity and phenolic content of selected fruit seeds. Food Chem. 2004, 88, 411-417. [CrossRef]

52. Balasundram, N.; Sundram, K.; Samman, S. Phenolic compounds in plants and agri-industrial by-products: Antioxidant activity, occurrence, and potential uses. Food Chem. 2006, 99, 191-203. [CrossRef]

53. Loizzo, M.R.; Tundis, R.; Bonesi, M.; Menichini, F.; Mastellone, V.; Avallone, L.; Menichini, F. Radical scavenging, antioxidant and metal chelating activities of Annona cherimola Mill.(cherimoya) peel and pulp in relation to their total phenolic and total flavonoid contents. J. Food Compost. Anal. 2012, 25, 179-184. [CrossRef]

54. Fahey, J.W. Moringa oleifera: A review of the medical evidence for its nutritional, therapeutic, and prophylactic properties. Part 1. Trees Life J. 2005, 1, 1-15.

55. Singh, B.N.; Singh, B.; Singh, R.; Prakash, D.; Dhakarey, R.; Upadhyay, G.; Singh, H. Oxidative DNA damage protective activity, antioxidant and anti-quorum sensing potentials of Moringa oleifera. Food Chem. Toxicol. 2009, 47, 1109-1116. [CrossRef]

56. Anwar, F.; Latif, S.; Ashraf, M.; Gilani, A.H. Moringa oleifera: A food plant with multiple medicinal uses. Phytother. Res. 2007, 21, 17-25. [CrossRef]

57. Tiloke, C.; Phulukdaree, A.; Chuturgoon, A.A. The antiproliferative effect of Moringa oleifera crude aqueous leaf extract on cancerous human alveolar epithelial cells. BMC Complement. Altern. Med. 2013, 13, 226. [CrossRef]

58. Vasanth, K.; Ilango, K.; MohanKumar, R.; Agrawal, A.; Dubey, G.P. Anticancer activity of Moringa oleifera mediated silver nanoparticles on human cervical carcinoma cells by apoptosis induction. Colloids Surf. B Biointerfaces 2014, 117, 354-359. [CrossRef] [PubMed]

59. Jung, I.L.; Lee, J.H.; Kang, S.C. A potential oral anticancer drug candidate, Moringa oleifera leaf extract, induces the apoptosis of human hepatocellular carcinoma cells. Oncol. Lett. 2015, 10, 1597-1604. [CrossRef]

60. Thorneloe, R.J.; Horne, R.; Side, L.; Wolf, M.S.; Smith, S.G.; Adamson, V.; Ainsworth, S.; Akerlund, M.; Baker, I.; Barwell, J. Beliefs about medication and uptake of preventive therapy in women at increased risk of breast cancer: Results from a multicenter prospective study. Clin. Breast Cancer 2019, 19, e116-e126. [CrossRef] [PubMed]

61. Cai, M.-Y.; Tong, Z.-T.; Zheng, F.; Liao, Y.-J.; Wang, Y.; Rao, H.-L.; Chen, Y.-C.; Wu, Q.-L.; Liu, Y.-H.; Guan, X.-Y. EZH2 protein: A promising immunomarker for the detection of hepatocellular carcinomas in liver needle biopsies. Gut 2011, 60, 967-976. [CrossRef] [PubMed]

62. Ferlay, J.; Soerjomataram, I.; Dikshit, R.; Eser, S.; Mathers, C.; Rebelo, M.; Parkin, D.M.; Forman, D.; Bray, F. Cancer incidence and mortality worldwide: Sources, methods and major patterns in GLOBOCAN 2012. Int. J. Cancer 2015, 136, E359-E386. [CrossRef] 